\title{
Communicating corporate social responsibility issues on Facebook's corporate fanpages of Latin American companies
}

\author{
Ileana Zeler; Paul Capriotti
}

How to cite this article:

Zeler, Ileana; Capriotti, Paul (2019). “Communicating corporate social responsibility issues on Facebook's corporate fanpages of Latin American companies". El profesional de la información, v. 28, n. 5, e280507.

https://doi.org/10.3145/epi.2019.sep.07

Manuscript received on $13^{\text {th }}$ February 2019 Accepted on $8^{\text {th }}$ May 2019

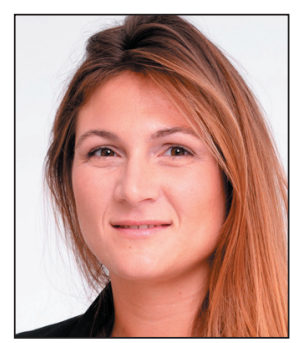

\author{
lleana Zeler $\square$ \\ https://orcid.org/0000-0002-5550-1000 \\ Universitat Rovira i Virgili \\ Departament of Communication Studies \\ Av. Catalunya, 35. 43002 Tarragona, Spain \\ ileana.zeler@urv.cat
}

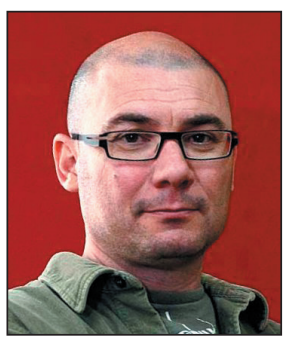

Paul Capriotti

http://orcid.org/0000-0002-9398-5886

Universitat Rovira i Virgili

Departament of Communication Studies

Av. Catalunya, 35. 43002 Tarragona, Spain

paul.capriotti@urv.cat

\begin{abstract}
The new organizational context in Latin America has changed the relationships between companies and stakeholders. Companies need to increase trust and transparency, and corporate social responsibility (CSR) communication can help Latin American companies become legitimated in the social environment by strengthening relationships with their stakeholders. This study analyzes how Latin American companies communicate their CSR activities to their stakeholders on Facebook. The research includes a specific analysis of CSR presence, activity, contents, and resources on the corporate fanpages. The results reveal that content about CSR topics are not frequently published in this social network. Companies focus their communication on their economic topics rather than their social issues, and they are using Facebook as a dissemination channel rather than as a communication channel. They mainly manage fanpages to obtain visibility, thereby missing the opportunity offered by the social network to promote dialogue and participation about CSR activities with their stakeholders.
\end{abstract}

\section{Keywords}

Latin America; Corporate social responsibility; Communication; Organizational communication; Internet; Social networks; Social media; Facebook; Reputation; Companies.

\section{Introduction}

Latin America (from now on LatAm) has undergone significant growth in the last 20 years. The regional private sector has been given a strong boost by the inflow of foreign capital and the creation and merger of companies (Yudira, 2007). The flow of capital has led to the growth of the local market and the entry of new foreign capital into the region, generating business mergers and new national and multinational companies. The new organizational context has changed the relationship between companies and their stakeholders. Companies need to increase trust and transparency, not only in terms of economic benefits, but also in terms of corporate social responsibility. The need to become more competitive and respond to economic and social responsibilities means that social and environmental issues can be integrated into the business strategy and the companies' practices become more responsible, particularly in labor and social issues that are relevant in the regional context (Peinado-Vara, 2011). CSR can help LatAm companies become integrated in the social environment to satisfy and strengthen relationships and achieve greater acceptance and recognition from their stakeholders. Lopata, Buchholz, and Kaspereit (2016) argue that CSR activities can increase the organization's level of trust since these activities improve the quality of earnings, transparency, and ethical standards. CSR communication has become more important because society considers it a legitimating activity for organizations (Capriotti; Moreno, 2007; Lee; Yoon; O’Donnell, 2018). 
The conception of what corporate responsibility is has evolved over the last 50 years. Authors who analyze the evolution of CSR (Carroll, 1999; Waddock, 2004; Wartick; Cochran, 1985; Wood, 1991) clearly differentiate between two broad corporate responsibilities:

- the economic-legal responsibilities, related to produce good products and services, to obey the law, and to earn increasing profits; and

- the social-ethical-philanthropic responsibilities of a company, linked to a respect for human rights, to care for the environment, and to make a social contribution to the community.

This means that companies should fulfill a social role (linked to their social responsibilities) in relation to their stakeholders, which goes beyond their purely economic-legal functions (economic role) (Carroll, 1999; Waddock, 2004; Wartick; Cochran, 1985; Wood, 1991). The way in which these roles are carried out and communicated to the stakeholders can influence mental associations that people have about a company, that is, the corporate reputation. Authors like Eisenegger and Schranz (2011), Lee (2016), and Boccia and Sarnacchiaro (2018) affirm that communication of social attributes has a positive impact on the reputation of organizations.

The majority of stakeholders perceive that social and environmental responsibilities are factors that govern the formation of opinions about a company's reputation (Brønn; Brønn, 2003). By communicating responsible behavior, companies try to achieve trust and legitimacy. But the positive effects of a good reputation are produced when stakeholders are involved in the communication of these activities (Eisenegger; Schranz, 2011).

Companies are increasingly using digital platforms to disseminate information linked with their economic and social roles. But it seems that CSR activities are not usually communicated on Internet and social networks. Research has demonstrated that companies tend to focus their communication on their economic topics rather than their social issues (Cho; Furey; Mohr, 2017; Etter, 2013; Haigh; Brubaker; Whiteside, 2013; Kim; Kim; Sung, 2014). Thus, a first specific objective is to determine what kind of CSR content companies are disseminating on Facebook.

Social networks have changed CSR communication. They have become a great "one-to-one" communication tool for companies, modifying the way that companies establish relationships with their stakeholders. Social media allow companies to communicate their CSR activities and establish interactive and symmetrical relationships with their public (Kim; Park; Wertz, 2010; Taylor; Kent, 2014). Some studies show the active participation of companies in social media is positively associated with corporate reputation (Dijkmans; Kerkhof; Beukeboom, 2015), so that organizations increasingly recognize the potential of social media. Companies affirm that social media are changing the way in which they engage and communicate with their different stakeholders.

The impact that the Internet and social networks have had on corporate communications has generated an evolution from traditional CSR communication to interactive CSR communication between organizations and stakeholders. In traditional CSR communication, an organization creates messages and disseminates them with the objective of informing or persuading its stakeholders about the nature of its identity, its organizational activities, and its values/products/services. With the impact of Web 2.0, CSR communication has become more interactive and symmetrical, promoting dialogic relationships between organizations and stakeholders and, subsequently, organizations must make a larger commitment to transparency and honesty. Several authors have affirmed that social networks are key tools for CSR communication (Capriotti, 2011; Carim; Warwick, 2013; Cortado; Chalmeta, 2016; DiStaso; McCorkindale, 2013). Research demonstrates that active participation of companies in social networks can have a positive impact on corporate reputation (Dijkmans et al., 2015; S. Lee, 2016).

Among social networks available, Facebook is the most popular. It allows companies to increase their visibility, listen actively, and generate participation and interaction with their stakeholders while offering the possibility of creating and spreading CSR content, as well as starting up dialogue and actively listening to the organization's stakeholders. The great acceptance of Facebook by Internet users and its exponential growth in recent years in the main LatAm countries (Fosk, 2017) favors the incorporation of this social network into the communication programmes of organizations.

Presence and activity on Facebook represent two key aspects of the analysis of CSR communication in this digital platform because they reveal whether companies recognize the importance of being permanent and actively present on Facebook in order to relate effectively and closely with their stakeholders. Therefore, a second specific objective is to analyze the level of presence and activity that companies maintain in this social network in relation to CSR issues.

To effectively communicate with stakeholders on Facebook, organizations can use information resources available in this social network. These information resources allow companies to create and disseminate content with a diversity of graphic resources (texts, images, and emojis), interactive resources (links, hashtags, and tags) and audiovisual resources (video-audio and GIFs). Studies indicate that information resources help organizations to improve their reach and interaction on Facebook (Von-Leoprechting, 2016) and to increase the engagement if they

Companies need to increase trust and transparency, not only in terms of economic benefits, but also in terms of corporate social responsibility 
create messages that encourage dialogue with their stakeholders (Abitbol; Lee, 2017). Thus, a third specific objective is to determine which kind of information resources companies are using to disseminate their CSR content on Facebook.

\section{Methods}

For this research, countries were selected with the highest GDP in the Statistical Yearbook of Latin America and the Caribbean of Eclac (Economic Commission of Latin America and The Caribbean), and in which the most important corporate, reputation annual study in LatAm (Merco) was carried out over a two-year period (2013 and 2014). Merco ranking was used because it is the most recognized reputation study in LatAm and it is the only one that covers the main countries of the region. The most reputable companies were selected because they are considered key players in communication management issues, they invest resources to improve innovation in digital communication, and they are leaders in CSR management. Finally, six countries were selected: Brazil, Mexico, Argentina, Colombia, Chile, and Peru.

In these countries, the first 35 companies in the Merco rankings were analyzed. Companies with an official, national corporate Facebook fanpage in 2015 and 2016 were chosen. Thus, the definitive sample included 135 Facebook profiles of LatAm companies ( 25 from Brazil, 19 from Mexico, 23 from Argentina, 27 from Colombia, 19 from Chile, and 22 from Peru).

Posts were selected for two weeks per month during a 12 month period: from January until June in 2015 and from July until December in 2016. Posts were compiled for the odd weeks in 2015 and the even weeks in 2016. Finally, a total of 29,078 posts were obtained.

Three research questions (RQ) were defined to fulfill the established objectives:

RQ1: Are the LatAm companies presenting their CSR issues on Facebook? What is their level of activity?

RQ2: What type of CSR content are companies disseminating through Facebook?

RQ3: Which kind of information resources are companies using to disseminate their CSR content on Facebook?

To answer research questions, three categories were defined based on presence and activity (RQ1), content (RQ2), and information resources (RQ3). These categories were developed and tested in previous research (Capriotti; Carretón; Castillo, 2016; Capriotti; Losada-Díaz, 2018; Capriotti; Ruesja, 2018; Cho; Furey; Mohr, 2017; DiStaso; McCorkindale, 2013).

For RQ1 we aimed to identify the profiles developed by companies on Facebook and to evaluate the volume of content disseminated by companies. For this, three dimensions were determined (two of presence and one of activity): the type of corporate page (if it corresponds to a fanpage or user profile); other specific pages (if companies present other commercial profiles, foundations, CSR, and/or CSR projects); and the level of activity (obtained from the daily average (D-AV) and weekly average (W-AV) of the companies' publications).

The Content category was established for RQ2 to identify the main topics that companies address. Three key dimensions were identified:

(a) Business issues: those related to the companies' business and commercial activities. For this dimension, four topics were identified:

- leadership (information related to business policies and strategies),

- results (information on business, financial, economic, and stock market results),

- commercial offer (information related to the characteristics of products, services, and brands), and

- innovation (information on key aspects of creative and productive innovation);

(b) CSR issues: those topics related to the company's corporate social responsibility in its daily activities. For this dimension, three topics were determined:

- governance (information linked to commitments, strategies, policies, and responsible practices at the level of corporate management, and commercial and marketing management),

- workplace (information on the company's labor and employment aspects and information on its commitments, strategies, policies, and responsible practices in relation to human resource management), and

- citizenship (information related to the company's commitments, strategies, policies, responsible practices at a social and environmental level); and

(c) Context issues: those issues related to the company's general situation and business sector. For this dimension, three topics were identified:

- general context (aspects that do not concern the business activity),

- sectorial context (aspects that concern the business activity), and

- relational context (aspects that concern the company's relationship with users).

The information resources category was established for RQ3 to determine resources used for disseminating content to the stakeholders. Seven tools were identified for this dimension: text, image (pictures, photos), GIF, audio-video, link, 
hashtag, tag users, and emoticons. Texts, images, and emoticons are considered graphic resources. GIFs and audio-video are recognized as audiovisual resources. Tag users, hashtags, and links are interactive resources. More than one possible resource can be included in the analysis of format.

We used content analysis as the methodology. A monitoring tool available on the Internet called Fanpage Karma was used to collect the posts. A template was designed to contain all the data collected from the sample. The information obtained during the research was coded in Excel templates specifically designed for this research.

\section{Results}

The results obtained are presented below, organized in relation to the RQs developed in the previous section.

\section{Presence and activity (RQ1)}

The results indicate that companies mostly had corporate fanpages and frequent activity on Facebook.

The presence on Facebook of LatAm companies was around 85\% (Table 1). Although Argentina, Brazil, and Colombia had a greater presence (more than $85 \%$ ), Mexican companies had a presence that barely exceeded $70 \%$ of the total, and Chile, Peru, and Mexico were below the average (around 80\%).

Table 1. Presence of companies on Facebook

\begin{tabular}{|c|c|c|c|c|c|c|c|}
\hline & LatAm & Argentina & Brazil & Chile & Colombia & Mexico & Peru \\
\hline \multicolumn{8}{|c|}{ Corporate fanpages (\%) } \\
\hline Yes & 86.5 & 88.5 & 92.6 & 82.6 & 90.0 & 82.6 & 78.6 \\
\hline No & 13.5 & 11.5 & 7.4 & 17.4 & 10.0 & 17.4 & 21.4 \\
\hline \multicolumn{8}{|c|}{ Other specific pages (\%) } \\
\hline CSR profiles & 29.6 & 17.4 & 36.0 & 15.8 & 42.3 & 31.6 & 31.8 \\
\hline Commercial profiles & 56.3 & 65.2 & 68.0 & 57.9 & 38.5 & 84.2 & 31.8 \\
\hline
\end{tabular}

In addition to corporate fanpages, there was a prominent presence of company fanpages related to CSR (CSR, CSR projects, etc.), reaching about $30 \%$ of companies. This means that one third of companies were using the social network specifically for CSR issues to inform their public about social projects and their commitment to the community and the environment. However, there were more commercial fanpages than CSR fanpages, since more than $50 \%$ of companies had them (Table 1).

There were significant differences in the presence of commercial and CSR profiles in certain LatAm countries. Mexico was the country with the largest number of companies with commercial profiles (84.2\%), followed by Argentina and Brazil (around 65\% each), and then Chile (almost 60\%). Colombia had the largest number of companies with profiles related to CSR (42.3\%), followed by Brazil (36\%), Mexico and Peru (around 30\% each). Although commercial profiles were the most common, Colombia had a higher percentage of CSR profiles when compared with commercial profiles (although the difference was not significant).

In relation to the activity, companies published content fairly frequently in their corporate fanpages. The analysis showed that each company published almost 1.2 posts per day.

The difference in the activity by country was not very relevant, except for Chile. Companies published at least 1 post per day; however, although Chile had the second lowest presence of companies on Facebook, results showed that this country had the most activity in the social network (1.8 posts per day per company).

About the issues companies covered on Facebook, in Table 2 it is observed CSR topics had an average of 0.2 posts per day per company-they were well below the average suggested daily activity. The activity of business issues represented 0.7 posts per company per day, that is, more than three times the average of CSR posts, which approached the average suggested daily activity more closely.

There were no significant differences among the LatAm countries in relation to CSR issues, except for Argentina.

Table 2. Business, CSR and context activities of companies on Facebook

\begin{tabular}{|l|c|c|c|c|}
\cline { 3 - 5 } \multicolumn{1}{c|}{} & Business & CSR & Context \\
\hline \multirow{3}{*}{ LatAm } & D-AV & 0.7 & 0.2 & 0.3 \\
\cline { 2 - 5 } & W-AV & 4.8 & 1.6 & 1.9 \\
\hline \multirow{3}{*}{ Argentina } & D-AV & 0.8 & 0.1 & 0.2 \\
\cline { 2 - 5 } & W-AV & 5.5 & 0.8 & 1.1 \\
\hline \multirow{3}{*}{ Brazil } & D-AV & 0.6 & 0.2 & 0.2 \\
\hline \multirow{3}{*}{ Chile } & W-AV & 4.0 & 1.3 & 1.4 \\
\hline \multirow{3}{*}{ Colombia } & D-AV & 1.0 & 0.3 & 0.5 \\
\cline { 2 - 5 } & W-AV & 6.7 & 2.1 & 3.3 \\
\cline { 2 - 5 } & D-AV & 0.7 & 0.3 & 0.3 \\
\hline \multirow{2}{*}{ Mexico } & W-AV & 4.9 & 2.1 & 1.8 \\
\hline & D-AV & 0.6 & 0.3 & 0.3 \\
\hline \multirow{2}{*}{ Peru } & W-AV & 4.2 & 2.3 & 1.8 \\
\hline & D-AV & 0.5 & 0.2 & 0.3 \\
\hline & W-AV & 3.5 & 1.4 & 2.1 \\
\hline
\end{tabular}


Table 6 shows that all countries had an average of between 0.1 and 0.3 posts per day per company (around one and two posts per week). This means that the presence of CSR issues was almost residual. In all the coun-

tries the average activity of business issues represented two or three times the activity of CSR topics, but in Argentina the difference was eight times. Regarding business issues, there was a significant difference among countries. Although the activity related to business issues represented the majority of posts, in the case of Peru, Mexico, and Brazil the average was between 0.5 and 0.6 , while in Colombia and Argentina the average was between 0.7 and 0.8 , and in Chile the average was one post per company per day (Table 2).

\section{Content (RQ2)}

Companies focused more on the dissemination of content related to business issues (around 60\% of cases), rather than CSR issues (almost 20\%). Most posts were related to the product and service offer (business), and to a lesser extent to citizenship (CSR) and leadership (business). The other topics, such as results, innovation, governance, and workplace, were below $4 \%$, with very little significance.

They also disseminated a lot of information about context issues (Table 3). More than $20 \%$ of posts were related to the general and sectorial situation of companies, and to aspects linked to the relationship between companies and users. They were informative, collaborative, and social posts. This indicates that companies were also interested in being informative referents on other topics of the social context in which they found themselves. They also manifested an intention to disseminate information that was closer to users (such as greetings, holiday days, motivational phrases, etc.).

Table 3. Content of companies on Facebook (\%)

\begin{tabular}{|l|c|c|c|c|c|c|c|c|c|c|}
\hline \multicolumn{9}{|c|}{ Business (\%) } & \multicolumn{4}{c|}{ CSR (\%) } \\
\hline & Total & Leadership & Results & Offer & Innovation & Total & Governance & Workplace & Citizenship & Total \\
\hline LatAm & 57.8 & 12.6 & 1.5 & 41.2 & 2.5 & 19.6 & 2.8 & 4.0 & 12.9 & 22.6 \\
\hline Argentina & 74.1 & 16.3 & 0.1 & 51.7 & 5.9 & 10.8 & 1.1 & 2.0 & 7.7 & 15.0 \\
\hline Brazil & 60.2 & 12.1 & 0.8 & 43.4 & 3.9 & 18.7 & 2.1 & 5.8 & 10.8 & 21.1 \\
\hline Chile & 55.4 & 11.3 & 0.7 & 42.5 & 1.0 & 17.5 & 3.2 & 3.4 & 10.9 \\
\hline Colombia & 56.3 & 13.1 & 5.4 & 36.7 & 1.1 & 23.5 & 3.6 & 2.9 & 17.0 \\
\hline Mexico & 50.9 & 10.8 & 0.5 & 37.5 & 2.2 & 27.5 & 4.2 & 2.9 \\
\hline Peru & 49.9 & 11.9 & 0.2 & 36.0 & 1.8 & 19.7 & 2.1 & 3.9 & 19.4 \\
\hline
\end{tabular}

Differences between the LatAm countries were not significant, but the case of Argentina should be noted. In this country the presence of posts on business issues represented a much higher percentage than in the rest of the countries (74.1\%).

Out of the total number of publications on business issues (Table 4), almost three quarters corresponded to the commercial offer (71.3\%). Posts on topics related to business strategy were detected in a lower percentage (around 20\%), and in a few cases there were posts on innovation (4.3\%) and business, financial, economic, and stock market results (2.6\%). These results were similar to those found in LatAm countries. However, in Colombia more content was published on results than on innovation.

Table 5 shows the results for posts on Corporate Social Responsibility issues. It can be observed that more than two thirds of the posts were related to citizenship (65.6\%) (about social and environmental aspects of companies). It should

Table 4. Business topics covered by companies on Facebook (\%)

\begin{tabular}{|l|c|c|c|c|}
\hline $\begin{array}{c}\text { Business } \\
\text { content }\end{array}$ & $\begin{array}{c}\text { Leadership } \\
\text { (\%) }\end{array}$ & $\begin{array}{c}\text { Results } \\
\text { (\%) }\end{array}$ & $\begin{array}{c}\text { Offer } \\
\text { (\%) }\end{array}$ & $\begin{array}{c}\text { Innovation } \\
\text { (\%) }\end{array}$ \\
\hline LatAm & 21.8 & 2.6 & 71.3 & 4.3 \\
\hline Argentina & 22.0 & 0.1 & 69.8 & 8.0 \\
\hline Brazil & 20.1 & 1.4 & 72.0 & 6.5 \\
\hline Chile & 20.3 & 1.2 & 76.7 & 1.8 \\
\hline Colombia & 23.3 & 9.6 & 65.2 & 1.9 \\
\hline Mexico & 21.1 & 1.0 & 73.6 & 4.3 \\
\hline Peru & 23.9 & 0.3 & 72.2 & 3.5 \\
\hline
\end{tabular}

Table 5. CSR topics covered by companies on Facebook (\%)

\begin{tabular}{|l|c|c|c|}
\hline CSR content & $\begin{array}{c}\text { Governance } \\
\text { (\%) }\end{array}$ & $\begin{array}{c}\text { Workplace } \\
\text { (\%) }\end{array}$ & $\begin{array}{c}\text { Citizenship } \\
\text { (\%) }\end{array}$ \\
\hline LatAm & 14.2 & 20.2 & 65.6 \\
\hline Argentina & 10.4 & 18.5 & 71.0 \\
\hline Brazil & 11.2 & 30.8 & 58.0 \\
\hline Chile & 18.5 & 19.5 & 62.0 \\
\hline Colombia & 15.2 & 12.4 & 72.4 \\
\hline Mexico & 15.2 & 14.2 & 70.6 \\
\hline Peru & 10.6 & 33.9 & 55.5 \\
\hline
\end{tabular}


also be noted that the governance issues (14.2\%) and workplace issues (20.2\%) had a presence that was three times less than citizenship issues.

Differences in the results by LatAm countries showed little significance. Citizenship issues were the most frequent posts of all LatAm countries, and Colombia $(72,4 \%)$ was the country that disseminated the most content on citizenship on their Facebook profiles, followed by Argentina (71\%) and Mexico (70,6\%). It should be noted that in Peru and Brazil, in addition to citizenship issues, companies prominently promoted workplace issues (more than $30 \%$ ).

\section{Information resources (RQ3)}

The results show that companies used graphic resources most often to disseminate content on Facebook. Almost all of the posts had text (97.8\%) and most had images (77.3\%) (Table 6). In a few cases emoticons were included in the publications. Although this resource was introduced by Facebook some time ago, just over $10 \%$ of publications used this graphic resource. Audiovisual resources were the least used by companies in LatAm to create and disseminate content on Facebook. The results indicate that just over $10 \%$ of the posts contained audio-video $(12.7 \%)$ and around $10 \%$ of the posts had GIFs.

Companies also used interactive resources such as links (40\%) and hashtags (50\%), even though the percentage was lower than text and image. In a few cases posts also had tags to users (15\%). This suggests that companies were implementing these resources to encourage interaction with users on Facebook.

Table 6. Information resources of companies on Facebook (\%)

\begin{tabular}{|c|c|c|c|c|c|c|c|c|}
\hline & \multicolumn{3}{|c|}{ Graphics (\%) } & \multicolumn{3}{|c|}{ Interactives (\%) } & \multicolumn{2}{|c|}{ Audiovisuals (\%) } \\
\hline & Text & Image & Emoticon & Tag user & Hashtag & Link & GIFs & Audio-Video \\
\hline LatAm & 97.8 & 77.3 & 12.1 & 15.8 & 40.6 & 48.6 & 8.6 & 12.7 \\
\hline Argentina & 96.8 & 82.3 & 14.3 & 22.1 & 46.0 & 51.7 & 7.5 & 12.3 \\
\hline Brazil & 97.3 & 73.9 & 20.1 & 15.1 & 33.5 & 64.3 & 5.6 & 15.1 \\
\hline Chile & 98.3 & 77.1 & 17.4 & 7.3 & 38.6 & 53.6 & 13.0 & 9.0 \\
\hline Colombia & 97.5 & 76.3 & 5.7 & 14.0 & 43.7 & 39.0 & 7.0 & 11.8 \\
\hline Mexico & 97.9 & 75.8 & 3.9 & 17.9 & 40.9 & 38.9 & 4.6 & 16.8 \\
\hline Peru & 98.8 & 79.1 & 11.1 & 23.0 & 40.2 & 45.5 & 14.1 & 13.2 \\
\hline
\end{tabular}

A detailed analysis among LatAm countries shows all of them mainly used graphic resources to create and disseminate posts (image and text). However, audiovisual resources point to differences among countries. In general, the use of audio-video was less frequent. Companies operating in Brazil and Mexico used audiovisual resources the most (around $15 \%$ ), and companies in Chile used them the least (less 10\%). Brazilian companies also used interactive resources the most, especially links. Almost $70 \%$ of the posts of companies in Brazil had a link, which was between $15 \%$ and $25 \%$ more often than the rest of the countries.

\section{Discussion}

The results show a significant number of companies still do not incorporate Facebook into their communication strategies (15\% of them). However, companies that had a presence on Facebook had a good level of activity. According to the recommendations of experts and professionals the appropriate average is one to two posts per day (Jordan, 2017; Patel, 2016). The results obtained show companies disseminate posts fairly frequently. These results are similar to those of other previous studies (Estudio de Comunicación, 2017; Kim; Kim; Sung, 2014).

Companies mainly created and managed fanpages to share information on business issues (basically about their commercial offer) and CSR issues were rarely found in company fanpages (less than 20\%). These findings reaffirmed what other authors have stated (Eisenegger; Schranz, 2011; Haigh; Brubaker; Whiteside, 2013), that is, that content disseminated by companies are mainly focused on business issues.

Companies are increasingly using Facebook to manage their online CSR communication (Cortado; Chalmeta, 2016), but they continue to give much more space to commercial issues and even to context topics. These results are in line with previous studies by authors such as Parveen, Jaafar, and Ainin (2014), who affirm that social networks are used for promotion and publicity, branding, research, and the construction of relationships with stakeholders, and to a much lesser extent to present and dialogue about their CSR activities.

Of CSR issues analyzed, companies focused mainly on the communication of social and environmental issues, giving very little space and interest to issues such as corporate governance and ethics, human resources, or em-
This research analyzes 29,078 posts of 135 Facebook profiles of Latin American companies 
ployment. Posts linked to these last two CSR topics were almost non-existent. This is a relevant fact because CSR issues are key for the communication of organizations because CSR communication contributes to boosting and strengthening their corporate reputation. As men-

tioned in the theoretical framework, social networks are key tools for CSR communication (Capriotti, 2011; Cortado; Chalmeta, 2016) and, therefore, they should be included in the communication strategy of organizations. The results show that companies rarely used their corporate fanpages to communicate their CSR activities.

CSR issues and context issues were covered similarly by companies. The difference between them was not significant. While in 2015 the context issues were represented in posts more than CSR issues (26\% against 17.5\%), in 2016 the volume of context posts decreased to between $10 \%$ and $20 \%$. This decrease in context posts indicates an increase in CSR issues.

Besides this, the results showed that companies were mostly using graphic resources to disseminate content (text and image), with very little audiovisual resources, which can be used to contribute effectively to the communicative activity (GIFs and audio-videos). Although audio-video resources imply a higher level of commitment, appeal more easily to emotion, and require more time and user attention to the story, they were not used for creating and disseminating content on Facebook. Previous studies show the use of audiovisual resources contributes to increasing the level of engagement (Pletikosa-Cvijikj; Michahelles, 2013; Quintly, 2016), unfortunately, companies in this study were missing out on the benefits that come from using videos.

\section{Conclusions}

The results achieved in this study provide an initial global exploration of CSR digital communication on Facebook in LatAm companies. Thus, the main ideas extracted from this study will encourage a future, deeper analysis on these topics.

Companies had a prominent presence and maintained fairly frequent activity on Facebook, but not as much as was expected for CSR issues. Their communication was focused on business issues (basically the commercial offer), and gave less importance to social issues. They mainly used graphic resources, but not so many audiovisual and interactive ones, instead focusing more on disseminating content rather than dialoguing and interacting with their stakeholders.

Thus, companies were focused on content dissemination with a mostly unidirectional communication approach, missing the opportunity that Facebook offers to promote a dialogue with their stakeholders. Companies that operate in LatAm recognized the importance of being present on Facebook in an active and permanent way, but they had a "one-way" communication approach. Information resources used by companies revealed a digital communication management strategy that was more unidirectional than bidirectional. Companies were not managing Facebook's tools and resources to promote interaction. By contrast, they were using the social network to share information.

Therefore, companies need to change the focus of their CSR communication. Their attention cannot only be oriented towards disseminating information and persuading stakeholders about the company's practices, but should also focus on facilitating dialogue and interacting with stakeholders about CSR issues, and integrating stakeholders in CSR activities and practices.

Finally, this research has some contributions, but also some limitations. It helped to develop a methodology that made it possible to analyze CSR communication management on Facebook in an integrated way. It was applied to a large number of companies and the results allowed us to show companies' Facebook communication strategy. From an academic point of view, this study can help to analyze the CSR communication of other organizations in specific countries or regions and make a comparative analysis. From the professional point of view, the results can con-

\section{LatAm companies are using Facebook as a dissemination channel rather than as a communication channel} tribute to detecting the strengths and weaknesses of CSR communication management on social networks, improving these practices in organizations. However, the methodology was applied to a specific study object (the main companies operating in LatAm) in a specific period of time; therefore, the results cannot be extrapolated to other companies or to another specific period of time.

Thus, future research could apply the methodology to other social networks (Twitter, Instagram, Snapchat, etc.) and also to other non-profit and for-profit organizations to determine whether the results found are replicated in another type of social network and for other organizations.

\section{References}

Abitbol, Alan; Lee, Sun-Young (2017). "Messages on CSR-dedicated Facebook pages: What works and what doesn't". Public relations review, v. 43, n. 4, pp. 796-808.

https://doi.org/10.1016/j.pubrev.2017.05.002 
Boccia, Flavio; Sarnacchiaro, Pasquale (2018). "The impact of corporate social responsibility on consumer preference: A structural equation analysis. Corporate social responsibility and environmental management, v. 25, n. 2, pp. 151-163. https://doi.org/10.1002/csr.1446

Brønn, Peggy-Simcic; Brønn, Carl (2003). "A reflective stakeholder approach: Co-orientation as a basis for communication and learning". Journal of communication management, v. 7, n. 4, pp. 291-303. https://doi.org/10.1108/13632540310807430

Capriotti, Paul (2011). "Communicating corporate social responsibility through the internet and social media”. In: Ihlen, $\emptyset$ yvind; Bartlett, Jennifer L.; May, Steve (eds.). The handbook of communication and corporate social responsibility, pp. 358-378. Boston: Wiley-Blackwell. ISBN: 9781444336344 https://doi.org/10.1002/9781118083246

Capriotti, Paul; Carretón, Carmen; Castillo, Antonio (2016). "Testing the level of interactivity of institutional websites: From museums 1.0 to museums 2.0". International journal of information management, v. 36, n. 1, pp. 97-104. https://doi.org/10.1016/j.ijinfomgt.2015.10.003

Capriotti, Paul; Losada-Díaz, José-Carlos (2018). "Facebook as a dialogic communication tool at the most visited museums of the world". El profesional de la información, v. 27, n. 3, pp. 642-650.

https://doi.org/10.3145/epi.2018.may.17

Capriotti, Paul; Moreno, Ángeles (2007). “Communicating corporate responsibility through corporate web sites in Spain". Corporate communications: An international journal, v. 12, n. 3, pp. 221-237. https://doi.org/10.1108/13563280710776833

Capriotti, Paul; Ruesja, Laura (2018). "How CEOs use Twitter : A comparative analysis of global and Latin American companies". International journal of information management, v. 39, 242-248.

https://doi.org/10.1016/j.ijinfomgt.2018.01.003

Carim, L.; Warwick, Claire (2013). "Use of social media for corporate communications by research-funding organisations in the UK". Public relations review, v. 39, n. 5, pp. 521-525.

https://doi.org/10.1016/j.pubrev.2013.08.006

Carroll, Archie B. (1999). “Corporate social responsibility”. Business and society, v. 38, n. 3, pp. 268-295. https://doi.org/10.1177/000765039903800303

Cho, Moonhee; Furey, Lauren D.; Mohr, Tiffany (2017). “Communicating corporate social responsibility on social media: Strategies, stakeholders, and public engagement on corporate Facebook". Business and professional communication quarterly, v. 80, n. 1, pp. 52-69.

https://doi.org/10.1177/2329490616663708

Cortado, Francisco-Javier; Chalmeta, Ricardo (2016). "Use of social networks as a CSR communication tool". Cogent business \& management, v. 3, n. 1, e1187783.

https://doi.org/10.1080/23311975.2016.1187783

Dijkmans, Corné; Kerkhof, Peter; Beukeboom, Camiel J. (2015). “A stage to engage: Social media use and corporate reputation". Tourism management, v. 47, pp. 58-67.

https://doi.org/10.1016/j.tourman.2014.09.005

DiStaso, Marcia W.; McCorkindale, Tina (2013). "A benchmark analysis of the strategic use of social media for Fortune's most admired U.S. companies on Facebook, Twitter and YouTube". Public relations journal, v. 7, n. 1, pp. 1-33.

https://prjournal.instituteforpr.org/wp-content/uploads/2013DiStasoMcCorkindale.pdf

Eisenegger, Mark; Schranz, Mario (2011). "Reputation management and corporate social responsibility". In: Ihlen, $\varnothing y$ vind; Bartlett, Jennifer L.; May, Steve (eds.). The handbook of communication and corporate social responsibility, pp. 129-146. Boston: Wiley-Blackwell. ISBN: 9781444336344

https://doi.org/10.1002/9781118083246

Estudio de Comunicación (2017). Presencia de las empresas del Ibex 35 en el entorno digital. Tercera edición. https://www.estudiodecomunicacion.com/servicios/presencia-de-las-empresas-del-ibex35-en-el-entorno-digital

Etter, Michael (2013). "Reasons for low levels of interactivity (Non-) interactive CSR communication in Twitter". Public relations review, v. 39, n. 5, pp. 606-608.

https://doi.org/10.1016/j.pubrev.2013.06.003

Fosk, Alejandro (2017). 2017 Latam digital future in focus. ComScore. Miami.

https://www.comscore.com/lat/Insights/Presentations-and-Whitepapers/2017/2017-LATAM-Digital-Future-in-Focus 
Haigh, Michel M.; Brubaker, Pamela; Whiteside, Erin (2013). "Facebook: examining the information presented and its impact on stakeholders". Corporate communications: An international journal, v. 18, n. 1, pp. 52-69. https://doi.org/10.1108/13563281311294128

Jordan, Rachel B. (2017). "How frequently should I post to Facebook?”. 929 marketing creative, June 24. http://www.rachelbjordan.com/marketing-leadership-blog/how-frequently-should-i-post-to-facebook

Kim, Sora; Kim, Soo-Yeon; Sung, Kang-Hoon (2014). “Fortune 100 companies' Facebook strategies: corporate ability versus social responsibility". Journal of communication management, v. 18, n. 4, pp. 343-362.

https://doi.org/10.1108/JCOM-01-2012-0006

Kim, Sora; Park, Jae-Hee; Wertz, Emma K. (2010). “Expectation gaps between stakeholders and web-based corporate public relations efforts: Focusing on Fortune 500 corporate web sites". Public relations review, v. 36, n. 3, pp. $215-221$. https://doi.org/10.1016/j.pubrev.2010.04.001

Lee, Sun-Young (2016). "How can companies succeed in forming CSR reputation?”. Corporate communications: An international journal, v. 21, n. 4, pp. 435-449.

https://doi.org/10.1108/CCIJ-01-2016-0009

Lee, Yoon-Joo; Yoon, Hye-Jin; O’Donnell, Nicole H. (2018). “The effects of information cues on perceived legitimacy of companies that promote corporate social responsibility initiatives on social networking sites". Journal of business research, v. 83, pp. 202-214.

https://doi.org/10.1016/j.jbusres.2017.09.039

Lopatta, Kerstin; Buchholz, Frerich; Kaspereit, Thomas (2016). "Asymmetric information and corporate social responsibility". Business \& society, v. 55, n. 3, pp. 458-488.

https://doi.org/10.1177/0007650315575488

Parveen, Farzana; Jaafar, Noor-Ismawati; Ainin, Sulaiman (2014). “Social media usage and organizational performance: Reflections of Malaysian social media managers". Telematics and informatics, v. 32, n. 1, pp. 67-78.

https://doi.org/10.1016/j.tele.2014.03.001

Patel, Neil (2016). "How frequently you should post on social media according to the pros". Forbes, Sep. 12.

https://www.forbes.com/sites/neilpatel/2016/09/12/how-frequently-you-should-post-on-social-media-according-tothe-pros

Peinado-Vara, Estrella (2011). “RSE en América Latina”. In: Vives, Antonio; Peinado-Vara, Estrella (eds.). RSE. La responsabilidad social de la empresa en América Latina. Banco Interamericano de Desarrollo, pp. 65-82.

http://luisperera.com/Ip/Publicaciones_files/LIBRO\%2ORSE.pdf

Pletikosa-Cvijikj, Irena; Michahelles, Florian (2013). "Online engagement factors on Facebook brand pages". Social network analysis and mining, v. 3, n. 4, pp. 843-861.

https://doi.org/10.1007/s13278-013-0098-8

Taylor, Maureen; Kent, Michael L. (2014). "Dialogic engagement: Clarifying foundational concepts". Journal of public relations research, v. 26, n. 5, pp. 384-398.

https://doi.org/10.1080/1062726X.2014.956106

Von-Leoprechting, Leonie (2016). “Brand study H1 2016: How do 30 of the biggest brands use Facebook?”. Quintly, October 19.

https://www.quintly.com/blog/2016/10/30-biggest-brands-on-facebook-analyzed-in-depth

Waddock, Sandra (2004). "Parallel universes: Companies, academics, and the progress of corporate citizenship". Business and society review, v. 109, n. 1, pp. 5-42.

https://doi.org/10.1111/j.0045-3609.2004.00002.x

Wartick, Steven L.; Cochran, Phillip L. (1985). "The evolution of the corporate social performance model". Academy of management review, v. 10, n. 4, pp. 758-769.

https://doi.org/10.2307/258044

Wood, Donna J. (1991). “Corporate social performance revisited”. Academy of management review, v. 16, n. 4, pp. 691718.

https://doi.org/10.2307/258977

Yudira, Zapata (2007). "La inversión extranjera directa de la Unión Europea hacia América Latina: el método de entrada de las principales multinacionales eléctricas". Estudios gerenciales, v. 23, n. 105, pp. 39-55.

https://doi.org/10.1016/S0123-5923(07)70024-4 